\title{
Xenon view, butterfly wings and a strange squid
}

September's sharpest science shots, selected by Nature's photo team.

\section{Daniel Cressey}

03 October 2017

\section{CRISPR catches}

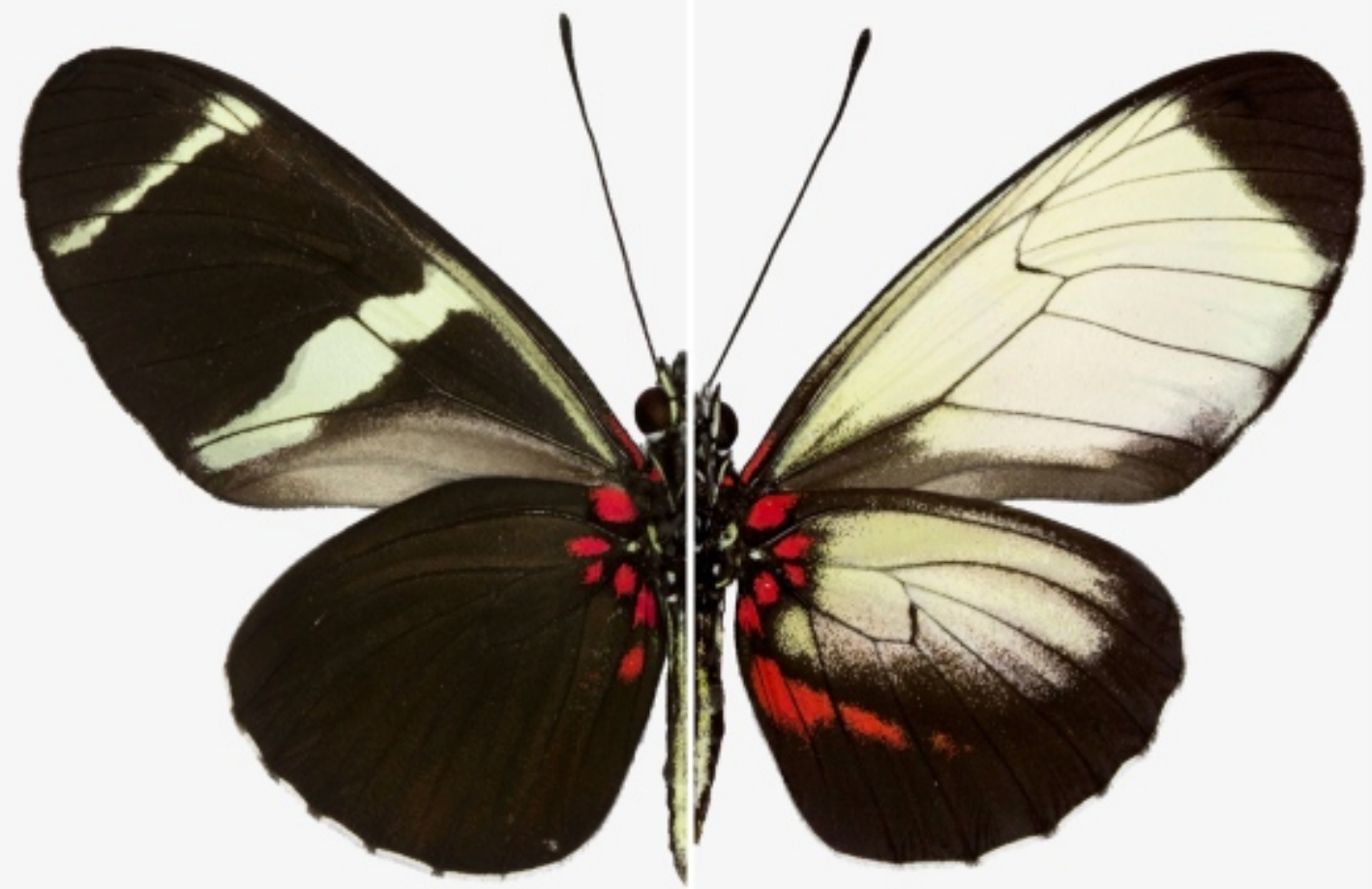

Richard Wallbank/Smithsonian Institution and University of Cambridge

The beauty of butterfly wings owes much to just two genes, researchers revealed this month. They used the CRISPR gene-editing system to turn off the genes, called WntA and optix, to show how their absence dulls the colours of these fleeting flyers. Left are the wings of an unmodified Sara longwing (Heliconius sara sara) from the study; right is a gene-edited version. 


\section{Inside Xenon}

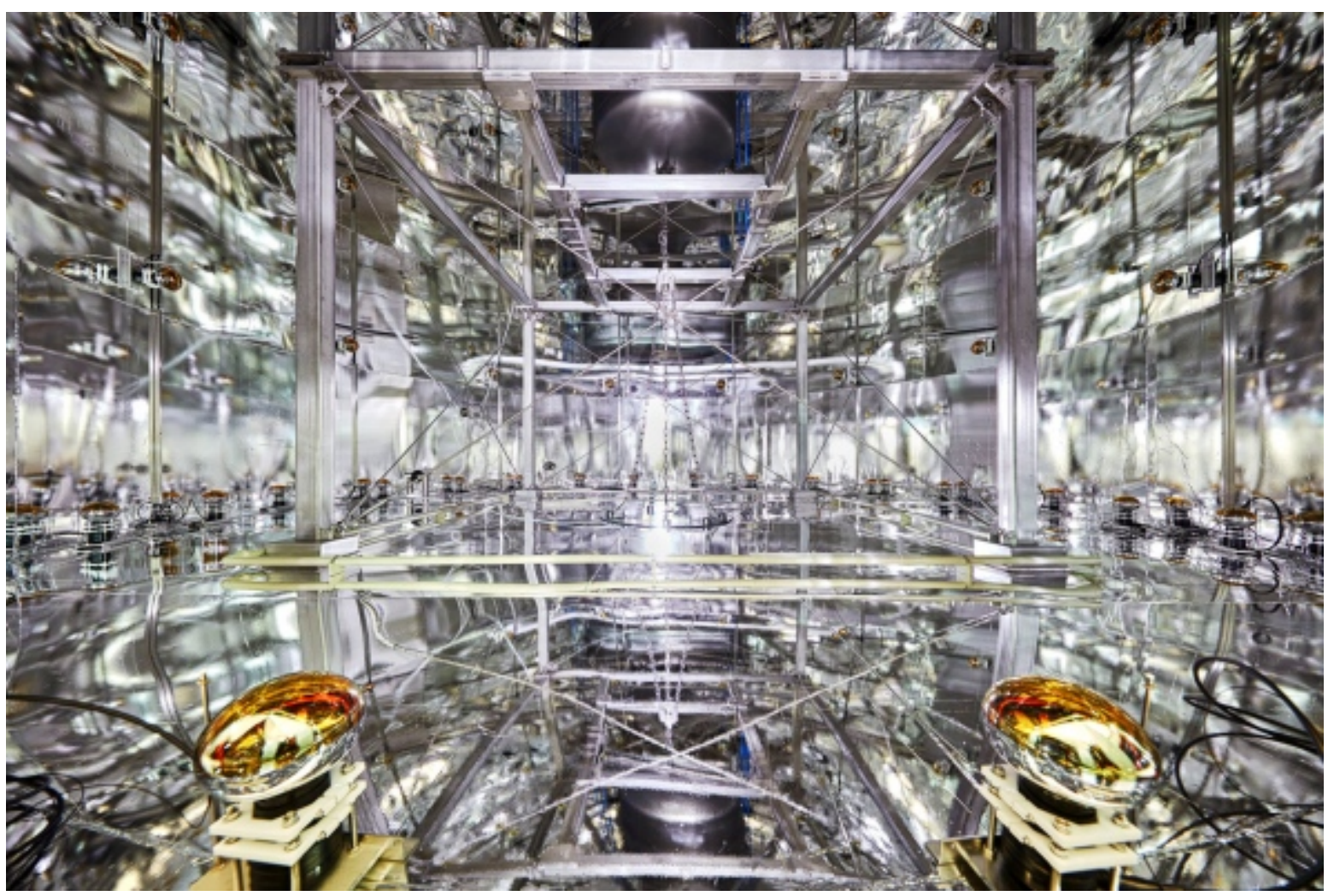

Winner of a gold award in the 2017 International Images for Science competition, this picture by Enrico Sacchetti shows the interior of the Xenon1T experiment at Italy's Gran Sasso Laboratory, which hunts for dark matter. 


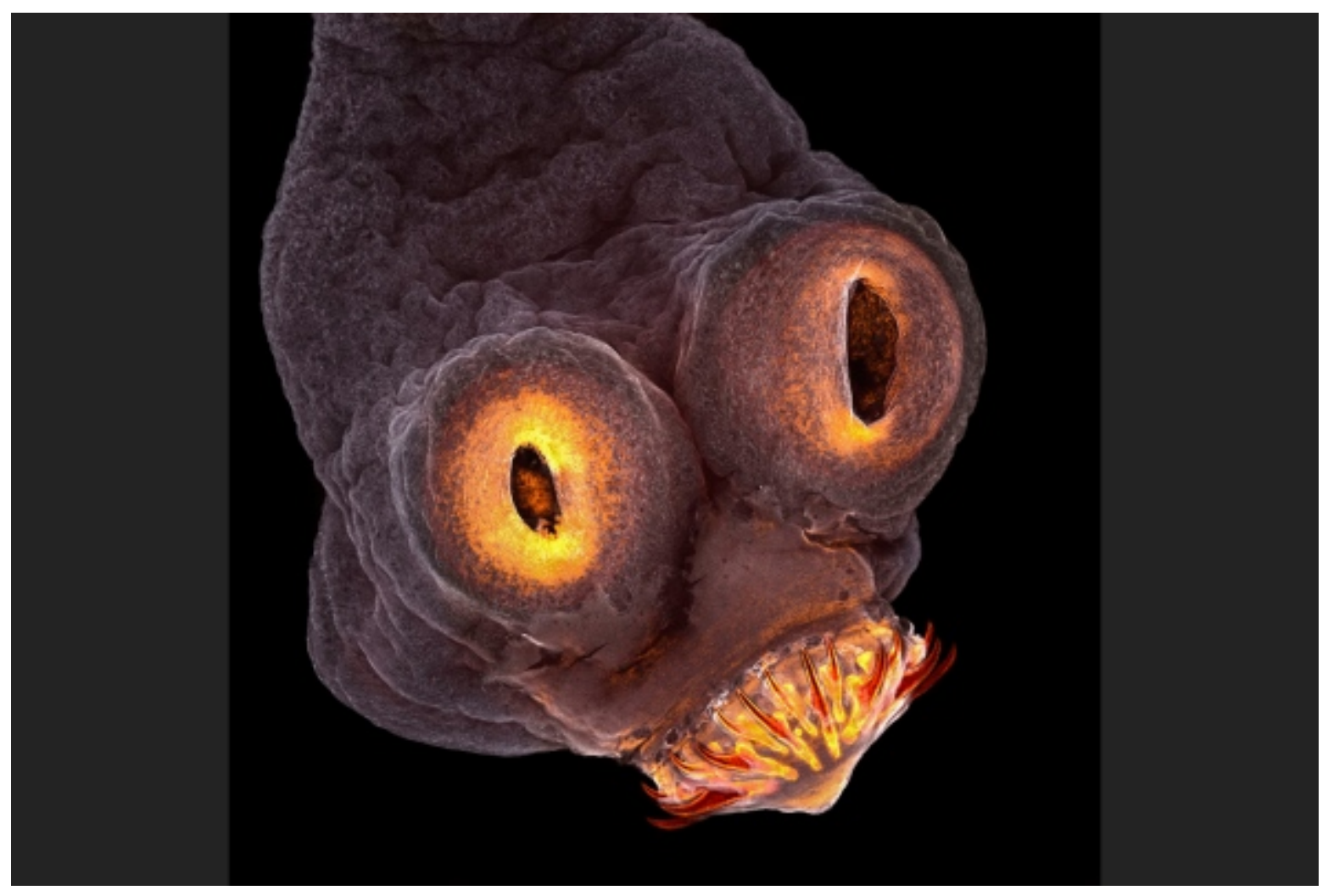

Another gold-award winner, this one taken by Teresa Zgoda. What looks like a frightening visage is actually a close-up of a pork tapeworm (Taenia solium), showing in detail the suckers that allow it to stick to the inside of humans and grow - and grow, and grow. 


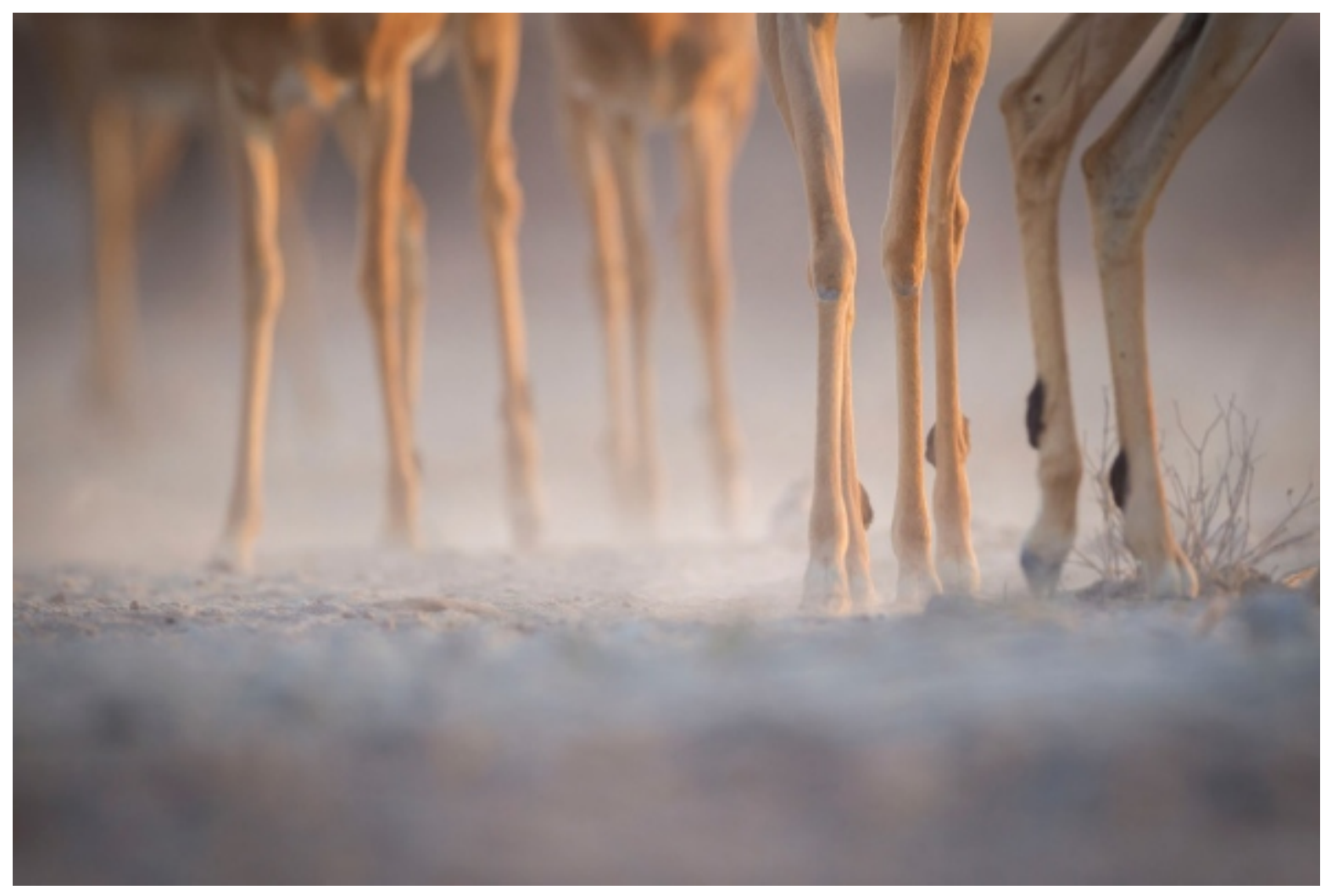

These legs belong to impalas (Aepyceros melampus); the black patches are glands used for scent marking. This image from Morgan Trimble won a bronze award in this year's competition.

Morgan Trimble/Royal Photographic Society 


\section{Coming down...}

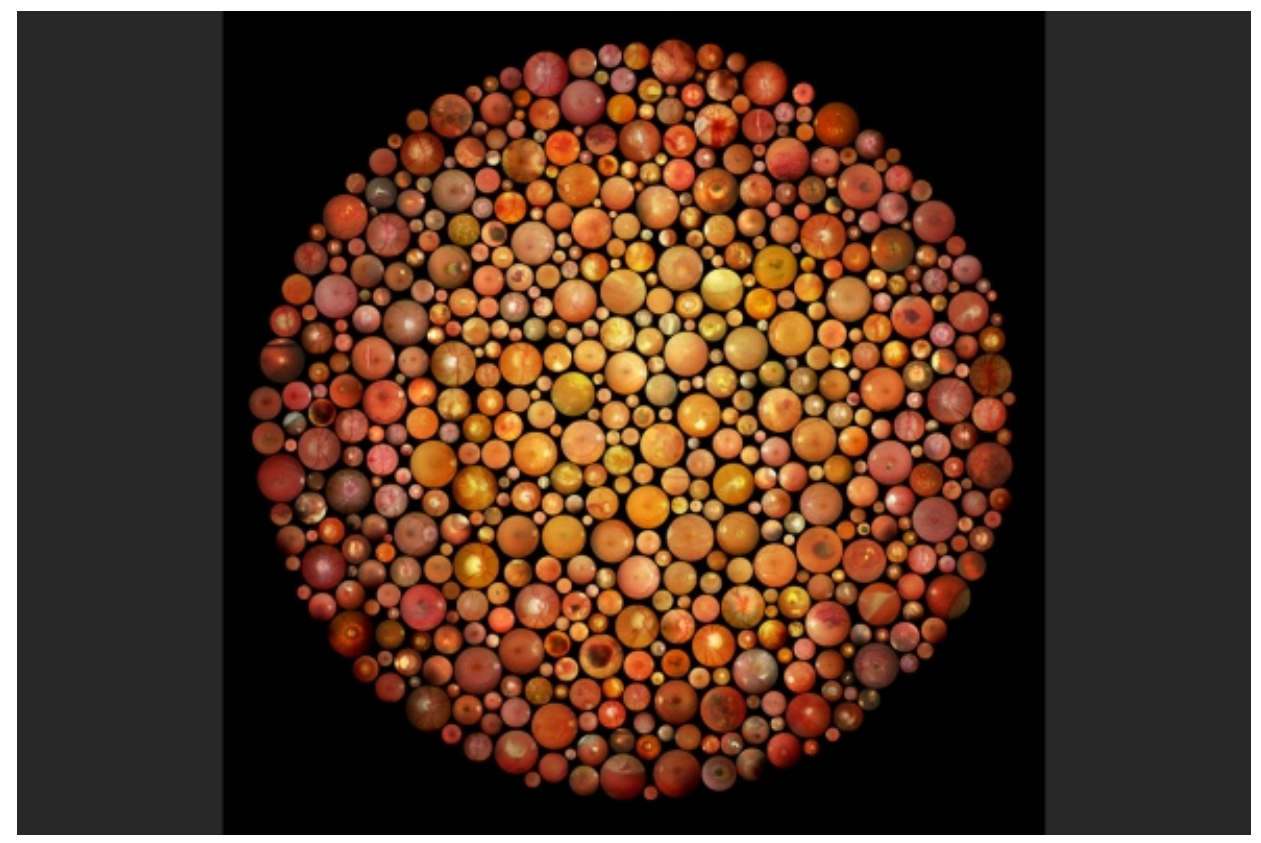

This shot is a combination of hundreds of images of retinas shot by Jonathan Brett, and assembled to mimic a colour-vision test chart. The eyes took a silver award.

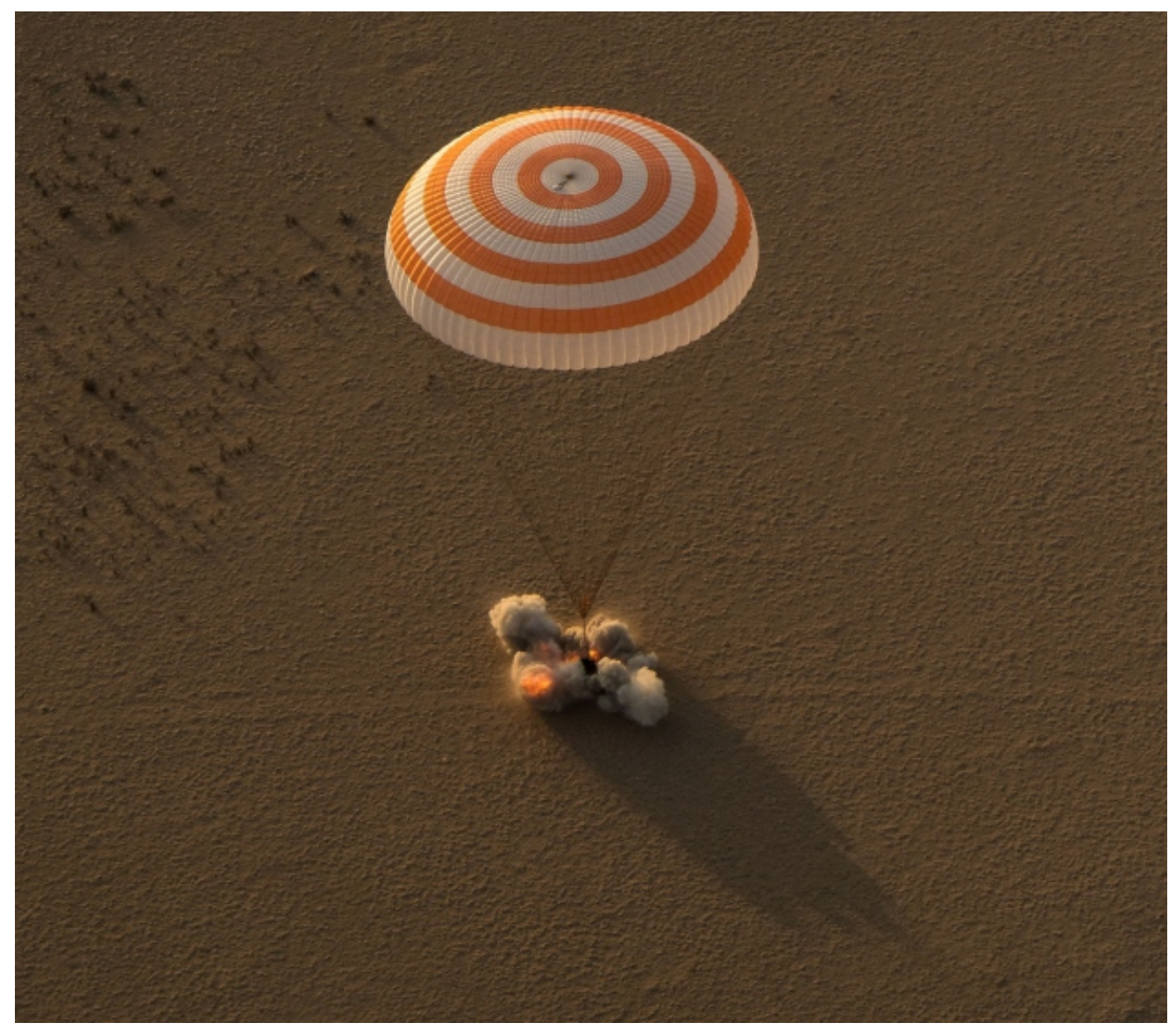

At the start of the month, this Soyuz capsule brought back three astronauts to Earth, landing near Zhezkazgan in Kazakhstan. Among them was Peggy Whitson, who spent 288 days in space aboard the International Space Station. 


\section{... and going up}

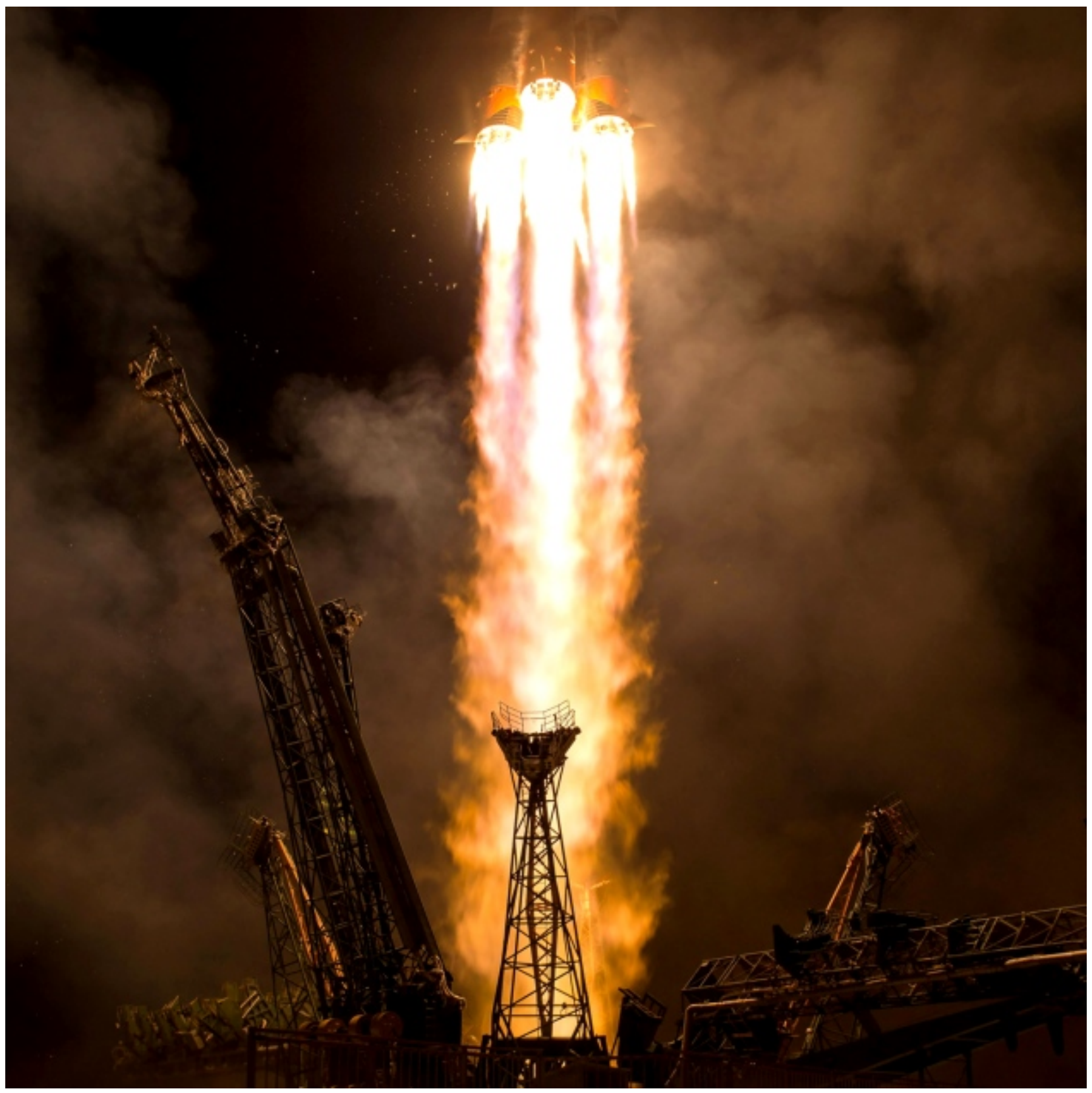

Bill Ingalls/NASA

Ten days after Whitson and her colleagues returned to this planet, another three people left it when this Soyuz left for the space station from Baikonur Cosmodrome. 


\section{A complex cloud}

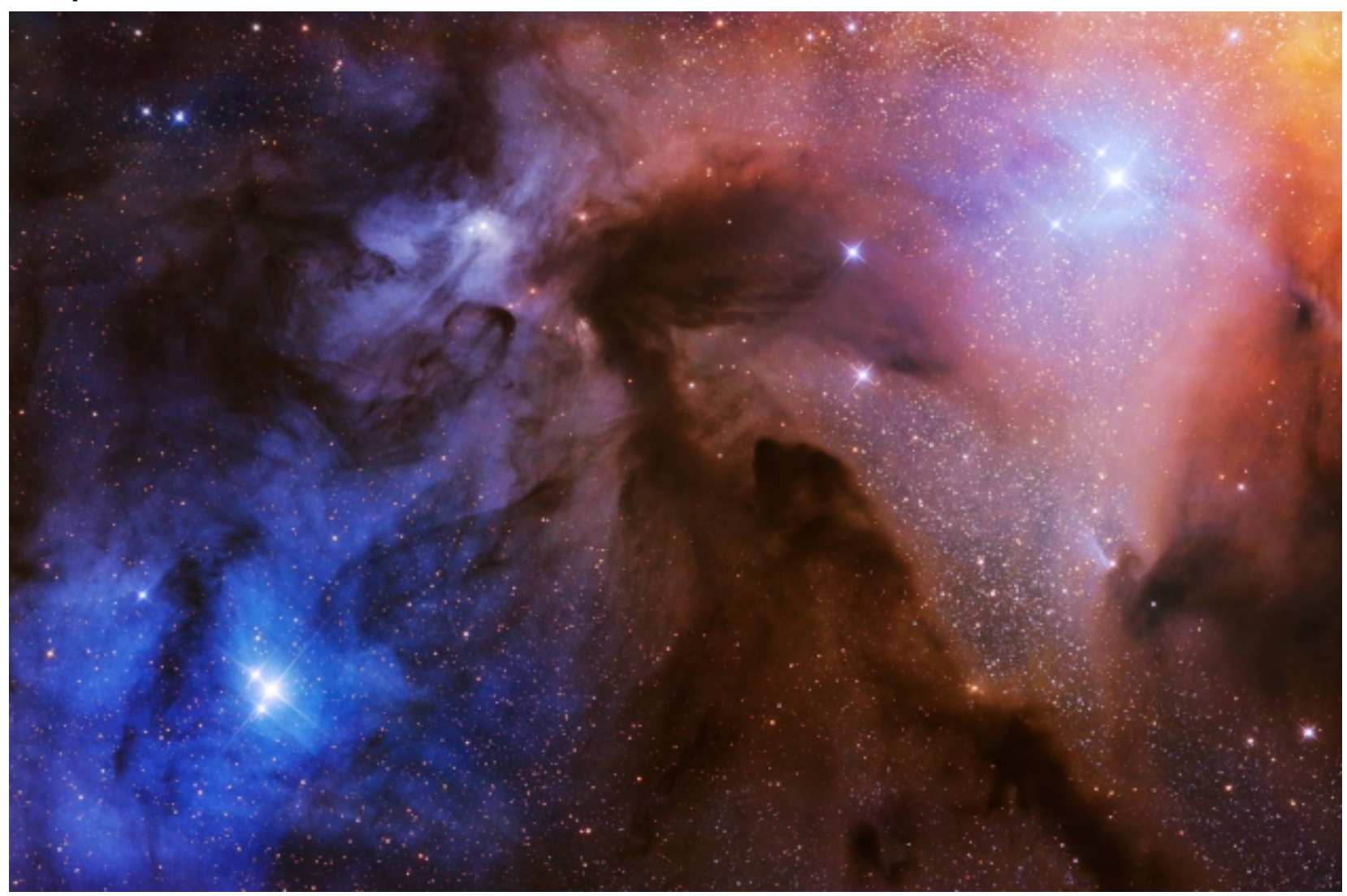

Artem Mironov

This nebula - called the Rho Ophiuchi cloud complex — is 140 parsecs (460 light years) from Earth. Photographer Artem Mironov took three nights to capture this image of it, which went on to win this year's Insight Astronomy Photographer of the Year award. 


\section{Seamount squid}

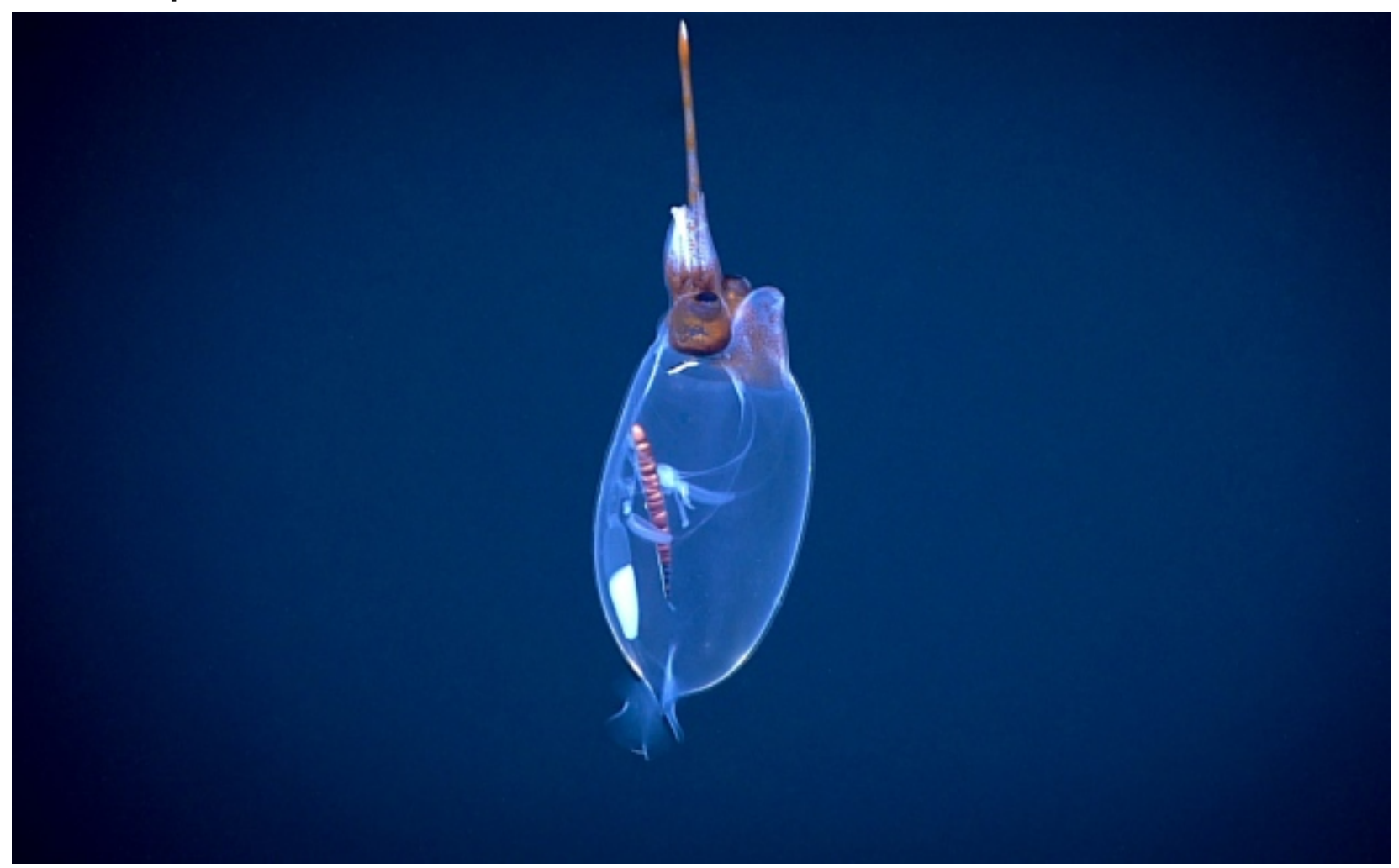

NOAA Office of Ocean Exploration and Research

On 17 September, the crew of the US National Oceanic and Atmospheric Administration's ship Okeanos Explorer were exploring the Musicians Seamounts, a formation of undersea mountains in the Pacific Ocean, with remotely operated submersibles when they spotted this cranchiid squid. You can see more pictures of weird and wonderful deep-sea denizens on their diary site. 


\section{Bee bounty}

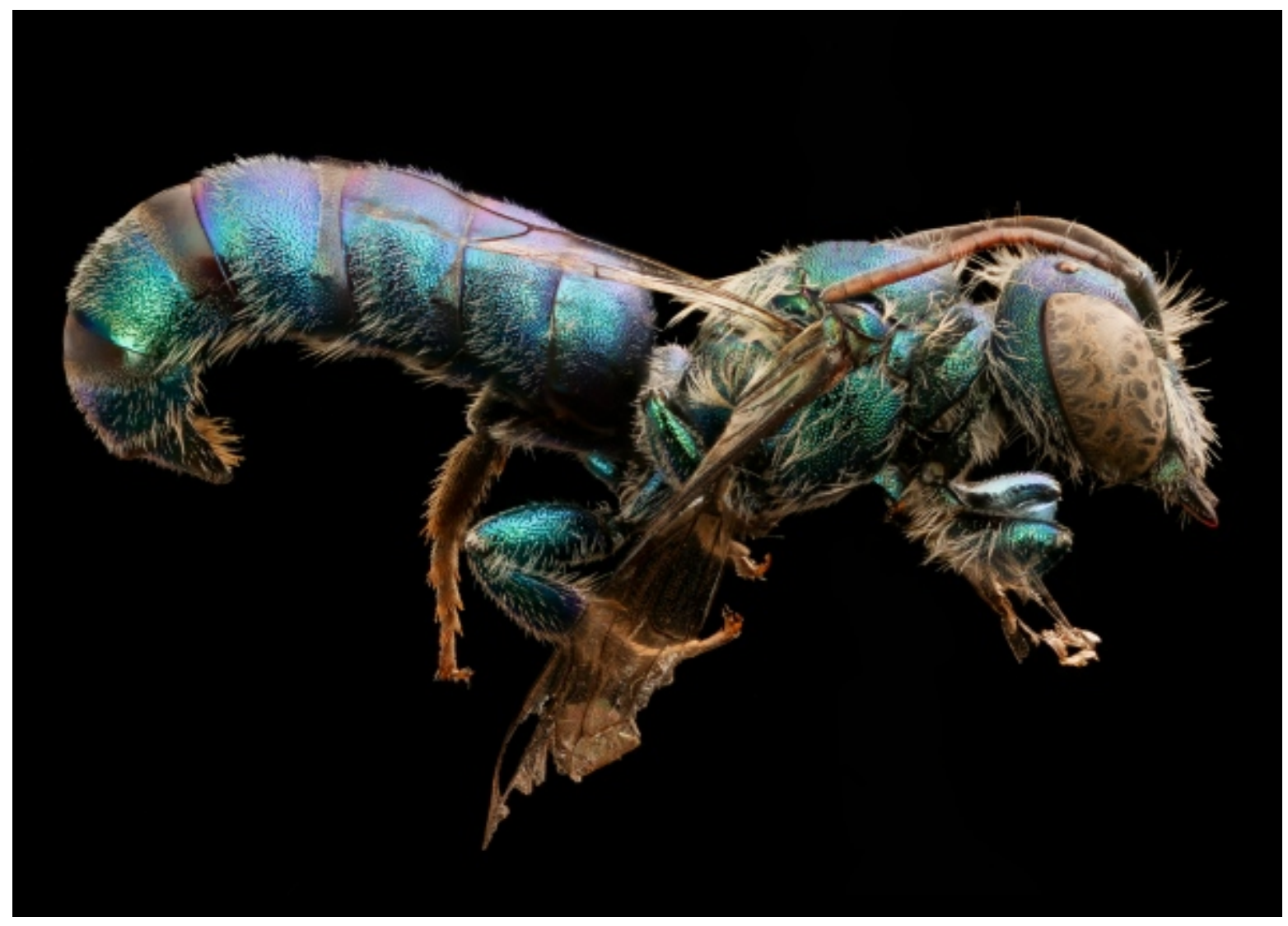

The USGS Bee Inventory and Monitoring Lab in Laurel, Maryland has long been among our favourite purveyors of online insect images. Among the latest additions to its catalogue is this Hoplitis fulgida. 


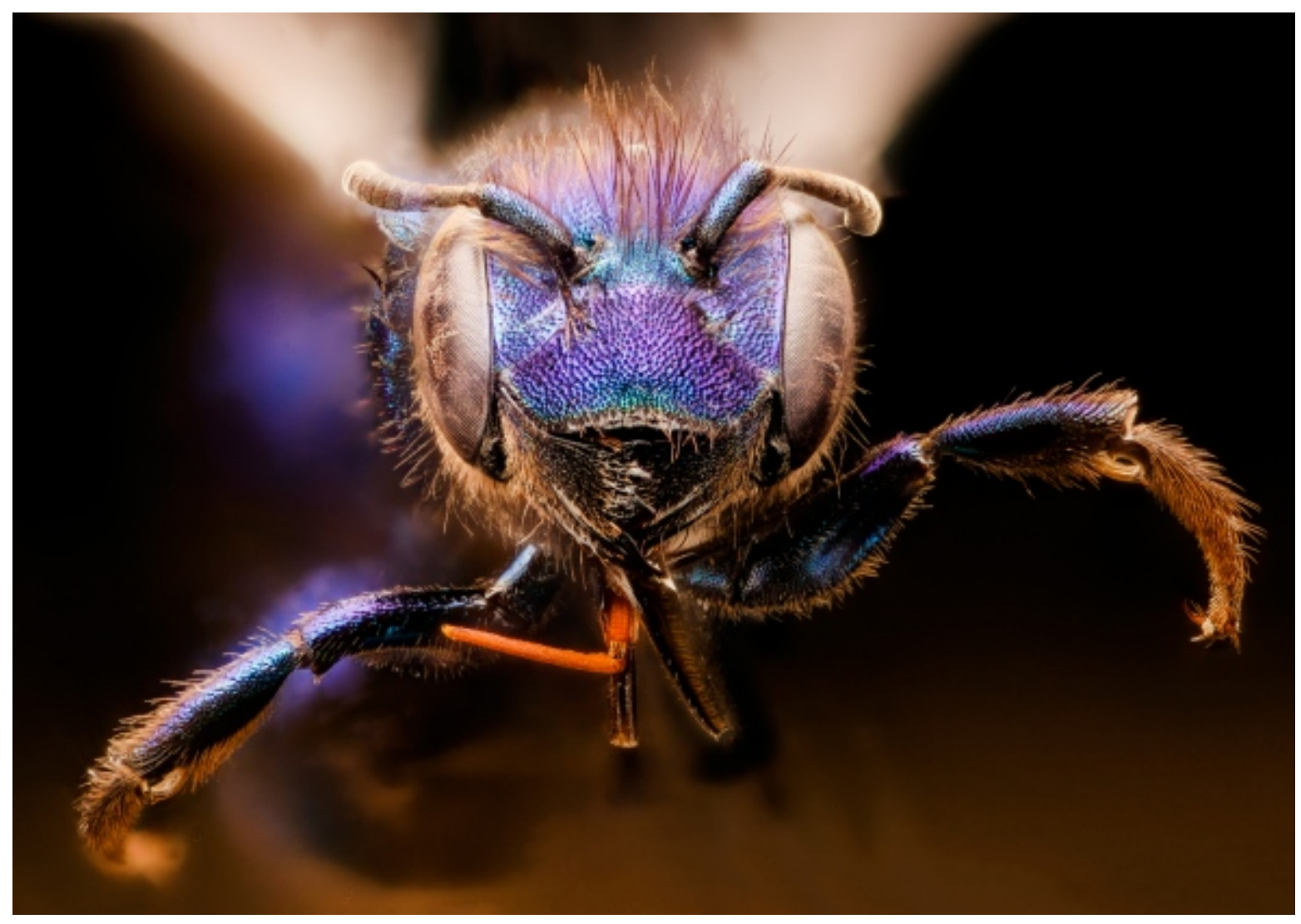

Another shot of $H$. fulgida, collected in Yosemite National Park, California.

USGS Bee Inventory and Monitoring Lab 


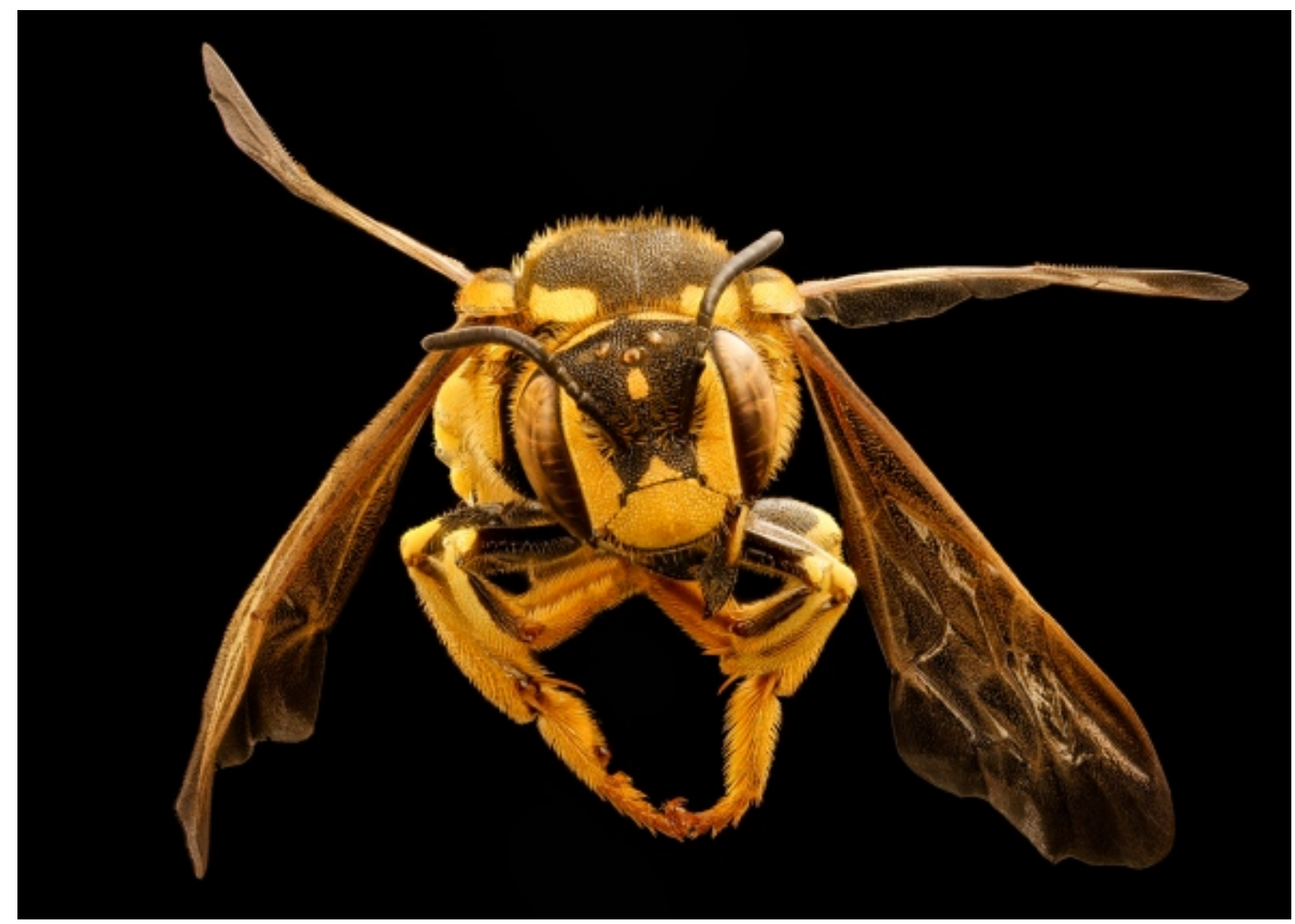

Dianthidium singulare glues rocks together to make little houses for its eggs. The lab calls it a "boss looking bee", and it's hard to disagree.

\section{Cassini comedown}

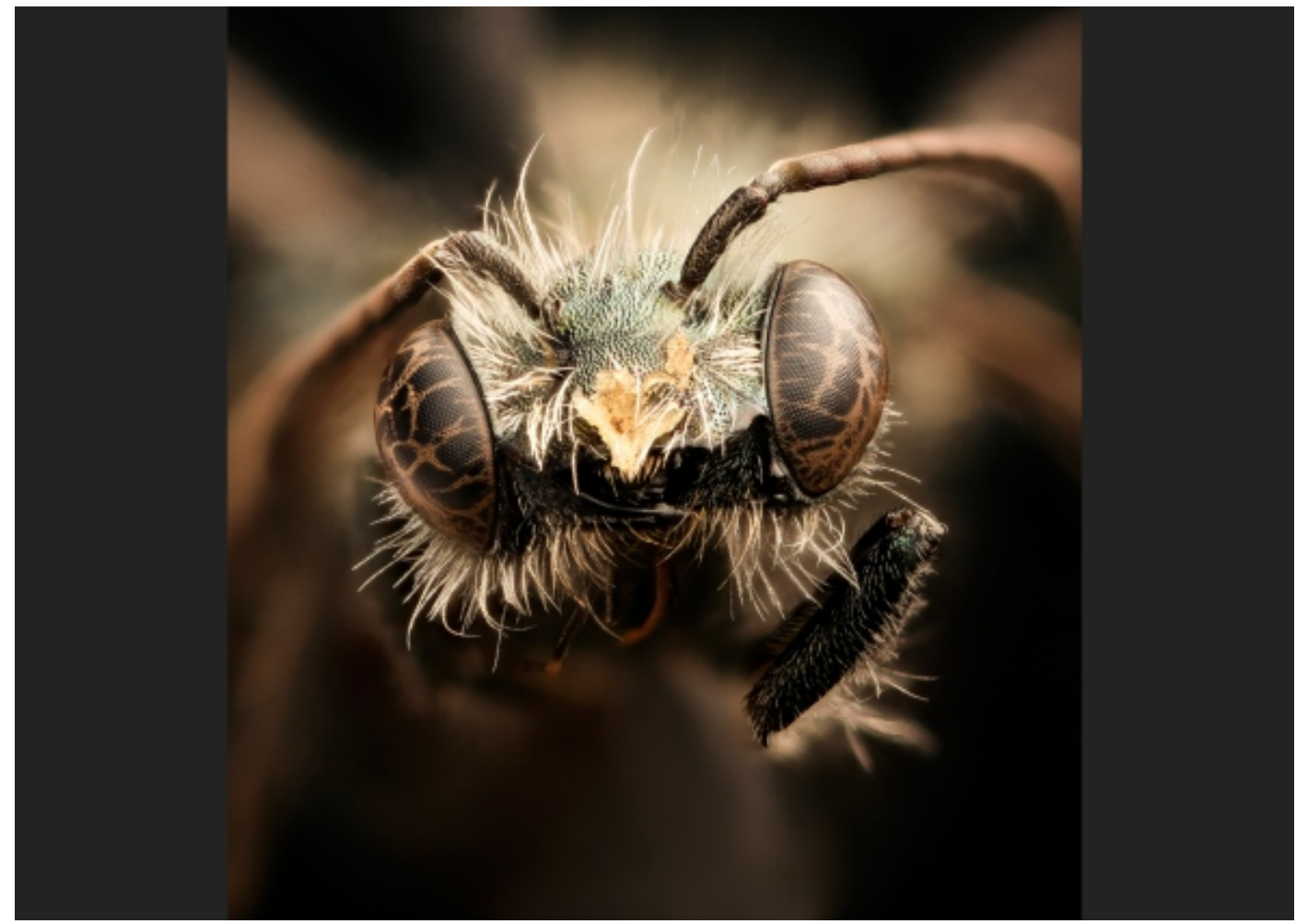




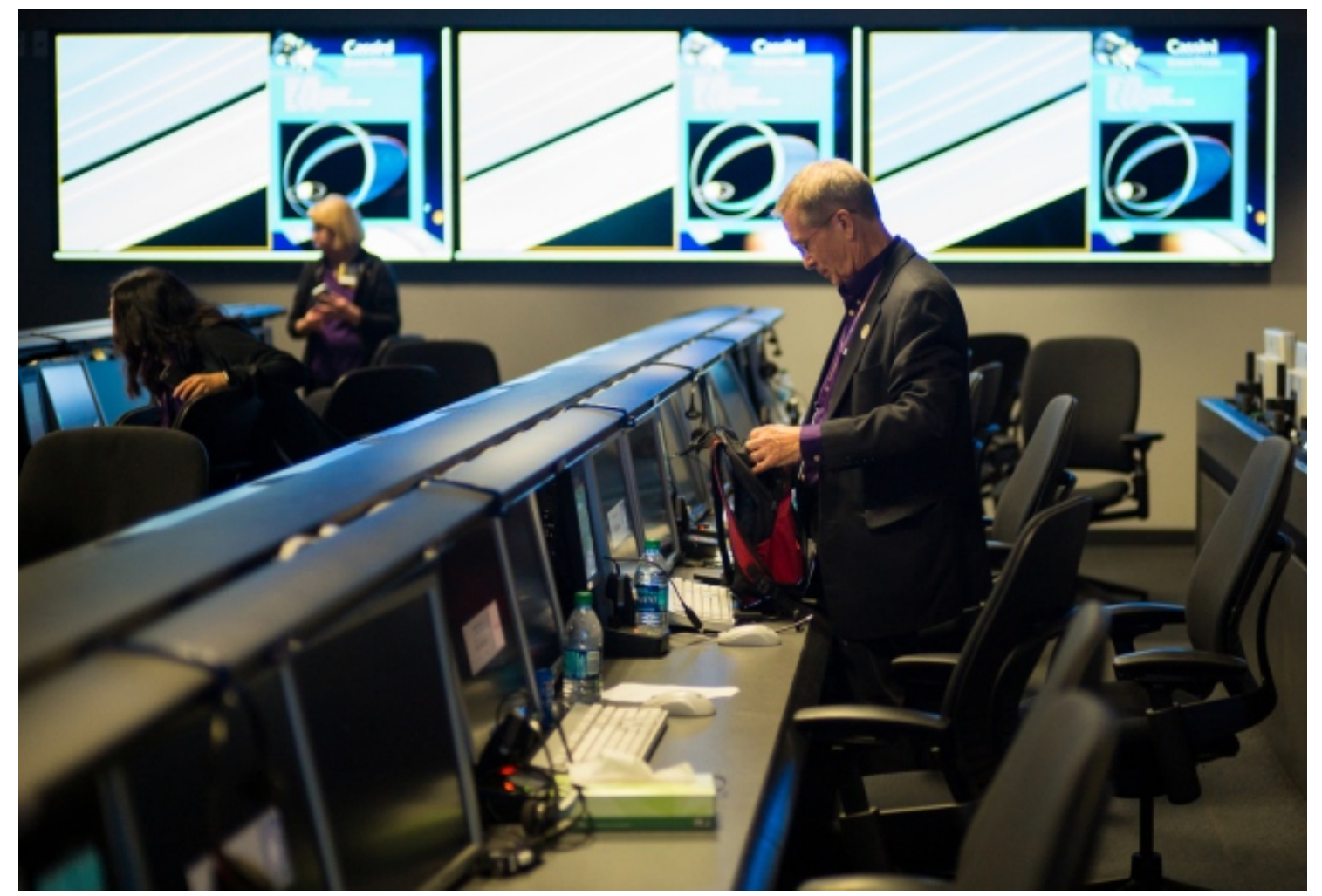

NASA/Joel Kowsky

The lab says this mason bee Osmia subarctica is a terrible specimen, but it has photographed beautifully.

It is finally over. The Cassini mission this month dived into Saturn's atmosphere, destroying itself. In this photo, Cassini programme manager Earl Maize packs up his workspacesatsmissiomicontrollim the det $b$ Propulsion Laboratory in Pasadena, California. on 15 September.

\section{They grow up so fast}

\section{Online Tracking of Arabidopsis Root}

Arabidopsis thaliana, or thale cress, is widely used as a model organism in labs. Daniel von Wangenheim of the Institute of Science and Technology Austria in Klosterneuburg won first place in the Nikon Small World in Motion Photomicrography Competition for this remarkable time-lapse video of the root tip of one $A$. thaliana plant growing. 